\title{
MAKNA GURU DALAM KONSEP TA'LIM, TARBIYYAH DAN TAZKIYYAH
}

\author{
Wawan Setiawan \\ UIN Sunan Gunung Djati Bandung \\ Jl. A.H Nasution No. 105 Cibiru Bandung \\ Email: wawansetiawan1953@gmail.com
}

\begin{abstract}
ABSTRAK
Tulisan ini bermaksud menganalisis konsep-konsep yang berhubungan dengan tugas dan fungsi guru seperti ta'lim, tarbiyyah, dan tazkiyyah dalam al-quran baik secara filosofis maupun pedagogis. Ada sejumlah tantangan baru untuk menafsirkan konsep-konsep tersebut agar kontekstual dengan tuntutan dan kebutuhan zaman. Hasil penelitian menunjukkan bahwa ta'lim bukan sekedar menyampaikan pengetahuan dan keterampilan, namun juga menekankan pada memberdayakan akal. Memberdayakan akal akan memungkinkan siswa mengembangkan kemampuan dalam memecahkan persoalan sehari-hari. Memberdayakan akal dapat mengantarkan siswa menyadari akan Kemahabesaran Allah. Orientasi tarbiyyah bermaksud mengembangkan potensi fisik, psikis, dan afeksi seperti menyangkut suasana hati, perasaan, citra diri, motivasi, ketahanan mental sebagai ciri ribbiyyûn. Tazkiyyah bertujuan mengembangkan kalbu sebagai tempat iman dan menghindari kemusyrikan. Kegiatan itu dilakukan dengan cara penanaman kebiasaan mengamalkan kewajiban agama berupa amalan ibadat disertai penghayatan akan Kemahabesaran Allah.
\end{abstract}

Kata Kunci : Guru, Ta'lim, Tarbiyyah, Tazkiyyah

\section{ABSTRACT}

This paper intends to analyze concepts associated to the duties and functions of a teacher such as, tarbiyyah, and tazkiyyah in al-Quran based on philosophical and pedagogical. There are a number of new challenges to interpret these concepts in order contextual with the demands and needs of the times. The results showed that the study groups is not just imparting knowledge and skills, but also emphasize the empowering sense. Empowering mind will enable students to develop skills in solving everyday problems. Empowering mind can deliver students aware of God's wisdom. Orientation tarbiyyah intends to develop the potential of physical, psychological, and affective concerns such as moods, feelings, self-image, motivation, mental toughness as a characteristic ribbiyyun. Tazkiyyah aims to develop heart as a place of faith, and avoiding polytheism. The activity was done by planting a religious duty to practice the habit of the practice of worship with the appreciation will be God's wisdom.

Keywords : Teacher, Ta'lim, Tarbiyyah, Tazkiyyah 


\section{PENDAHULUAN}

Dalam Al-Quran ada isyarat bahwa manusia disebut-sebut sebagai mahluk biologis (Al-Mu'minun: 2-16), psikologis (Al-Sajdah 9) dan sosial ( Al-'Alaq: 2) Dalam Surat Ar-Rum: 30 dinyatakan bahwa manusia dianugerahi kemampuan dasar atau fithra $h$ yang bukan hanya merupakan daya intelek, emosi dan bakat tetapi juga potensi teologis (tauhid). Artinya manusia diciptakan Allah swt mempunyai naluri selalu bergantung dan memerlukan kehadiran Tuhan. Pengembangan secara maksimal pada individu, atas semua aspek tersebut akan bergantung kepada pengaruh luar terutama dari pendidikan.

Karena pendidikan itu pada hakikatnya merupakan upaya memanusiakan manusia maka pendidikan seyogyanya diarahkan untuk mengelola seluruh anugerah dan potensi tersebut menjadi baik sekaligus meminimalisir menjadi jahat. Di dalam pendidikan ada interaksi antara pendidik dan peserta didik yang bertujuan (teleologis). Hubungan interaktif-harmonis antara pendidik (guru) dengan peserta didik (siswa) mesti dirancang dan dikelola secara profesional. Ujung tombak hubungan tersebut terletak pada kepiawaian guru dalam mengelola kelas. Dalam Undang-Undang N0.14 tahun 2005 Tentang Guru dan Dosen Bab I Ketentuan Umum pasal 1 ayat, dinyatakan bahwa "Guru adalah pendidik profesional dengan tugas utama mendidik, mengajar, membimbing, mengarahkan, melatih dan mengevaluasi peserta didik pada pendidikan anak usia dini jalur pendidikan formal, pendidikan dasar dan pendidikan menengah". Hal ini mengisyaratkan bahwa di lembaga formal persekolahan guru mengemban mendidik, mengajar, melatih sekaligus pembimbing siswa.

Tugas mengajar dan mendidik disebut tugas profesional layanan instruksional. Tugas layanan instruksional ini diarahkan pada pengembangan kemampuan baik kognisi maupun afeksi dan psikomotor. Tugas membimbing diarahkan pada pemberian bantuan menyelesaikan masalah siswa dalam belajar termasuk masalah-masalah pribadi yang berpotensi mengganggu keberhasilan belajarnya. Keberhasilan belajar di kelas, sering dipengaruhi pula oleh hal-hal yang berada di luar kelas (non akademik). Dalam Al-Quran, pengembangan seluruh aspek di atas bisa diupayakan melalui ta'lim, tarbiyyah dan tarkizyah. Tulisan ini berupaya menganalisis konsep-konsep tersebut baik secara filosofis maupun pedagogis. Ada sejumlah tantangan baru untuk menafsirkan konsepkonsep tersebut agar kontekstual dengan tuntutan dan kebutuhan zaman.

\section{PEMBAHASAN}

\section{Ta'lîm}

Kata ta'lim merupakan bentuk mashdar dari 'allama. Kata ini berasal dari 'alima yang berarti 'mengerti' atau 'mengetahui'. Kata 'allama termasuk kata kerja tsulâtsi mazîd dengan penambahan satu huruf pada 'ayn fi'l' (bitadlifi al'ayn) yang berfungsi ta'diyyat atau muta'addi dalam arti membutuhkan objek. Perpindahan wazn itu berpengaruh terhadap perubahan makna. Kata 'allama artinya 'mengajar' dan mengandung makna 'memberi tahu'. Tetapi setelah 
berubah menjadi mashdar (i'lâm) maknanya berubah menjadi 'memberitahu' atau 'pemberitahuan'. Raghib Asfahani,( tth: 356) menyatakan bahwa kata i' lâm dan ta' lim mempunyai makna yang sama, namun i'lâm lebih khusus bagi pemberitahuan yang sifatnya cepat, sedangkan ta' lim lebih tertuju kepada pemberitahuan yang dilakukan secara berulang-ulang.

Sebagai mashdar, kata ta' lim mempunyai fungsi ganda yakni sebagai kata kerja dan kata benda. Sebagai kata kerja ia berarti mengajar, sebagai kata benda berarti pengajaran. Dalam Al-Quran, kata ta' lìm dijumpai dalam bentuk mâdhh ('allama) dan mudhâri' (yu'allimu) yang terulang sebanyak 38 kali dalam 34 ayat.

\begin{tabular}{|c|c|c|c|c|}
\hline No & Ayat / Surat & Subjek & $\begin{array}{c}\text { Objek } \\
1\end{array}$ & $\begin{array}{c}\text { Objek } \\
2 \\
\end{array}$ \\
\hline 1 & 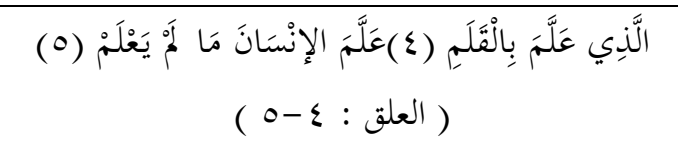 & هو\الله & انسان & Lo \\
\hline 2 & عَعلَّمَهُ شَدِيدُ الُْقُوى ( النجم : 0 ). & جبريل & محمد & \\
\hline 3 & 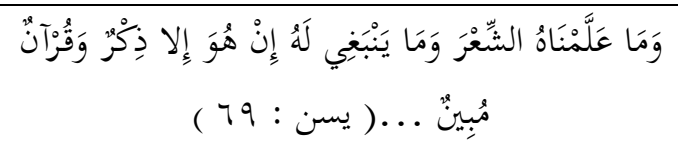 & نحن الله & محمد & الشّعر \\
\hline 4 & 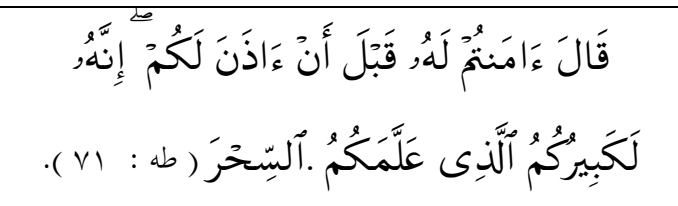 & فرعون & انتم & السحر \\
\hline 5 & 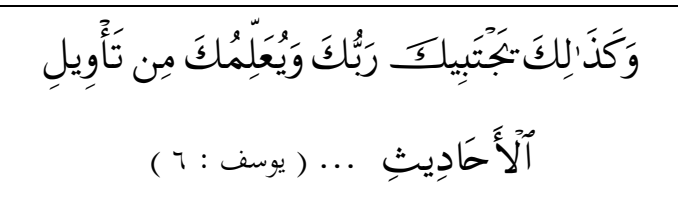 & ربك & انت إيوس & تأريل \\
\hline 6 & 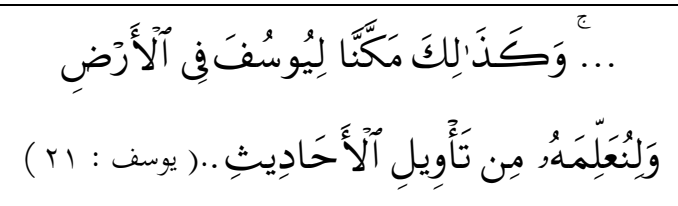 & نغن اللّ & يوسف & تأويل \\
\hline 7 & 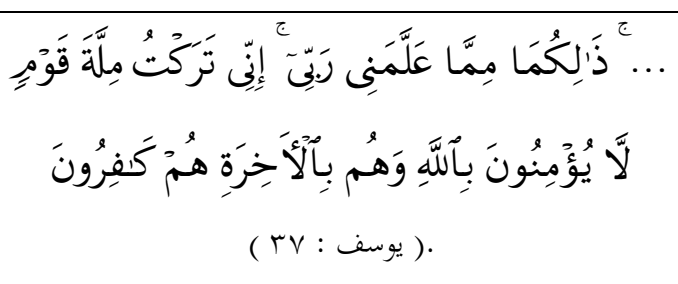 & ربّ & انايوسف & مثّا \\
\hline 8 & 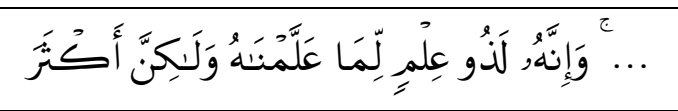 & نح \الله & هو يعقوب & علم \\
\hline
\end{tabular}


Wawan Setiawan

\begin{tabular}{|c|c|c|c|c|}
\hline No & Ayat / Surat & Subjek & $\begin{array}{c}\text { Objek } \\
1\end{array}$ & $\begin{array}{c}\text { Objek } \\
2\end{array}$ \\
\hline & 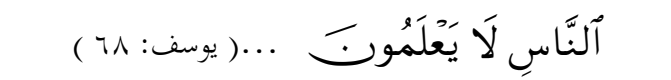 & & & \\
\hline 9 & 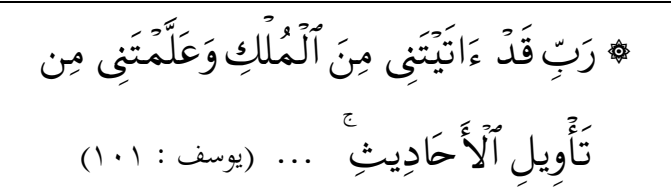 & انت ربّ & انا يوسف & تأويل \\
\hline 10 & 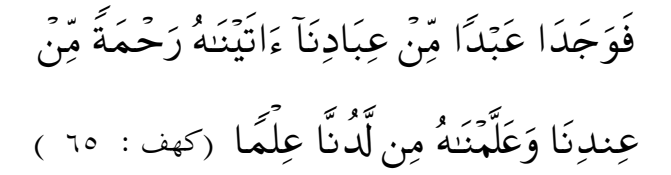 & نخن الله & حضر & علما \\
\hline 11 & 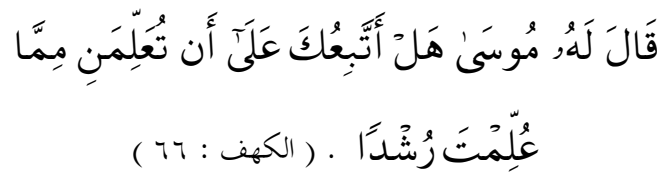 & حضر & انا موسى & علم \\
\hline 12 & 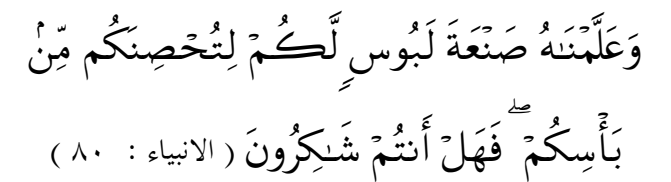 & نحن \الله & داوود & صنعة لبوس \\
\hline 13 & 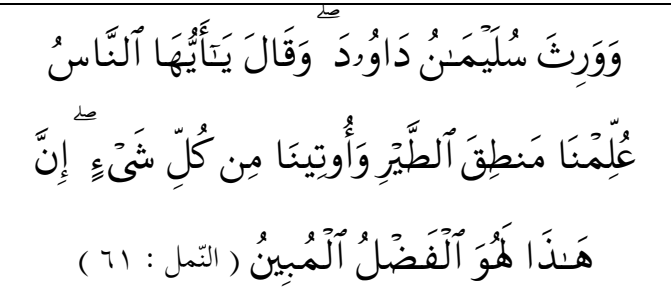 & اللة & سليمان & منطق الطّير \\
\hline 14 & 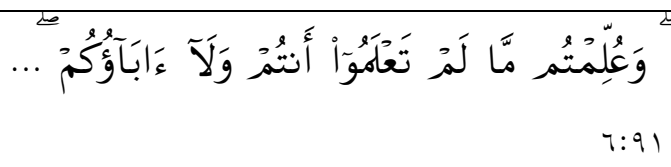 & لे & دم & L \\
\hline 15 & 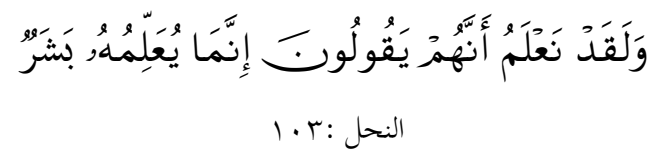 & بشر & محمد & \\
\hline 16 & 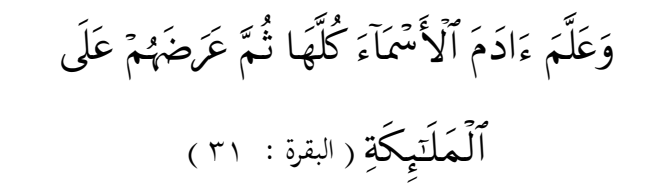 & الله & ادم & الاسماء \\
\hline
\end{tabular}


Makna Guru dalam...

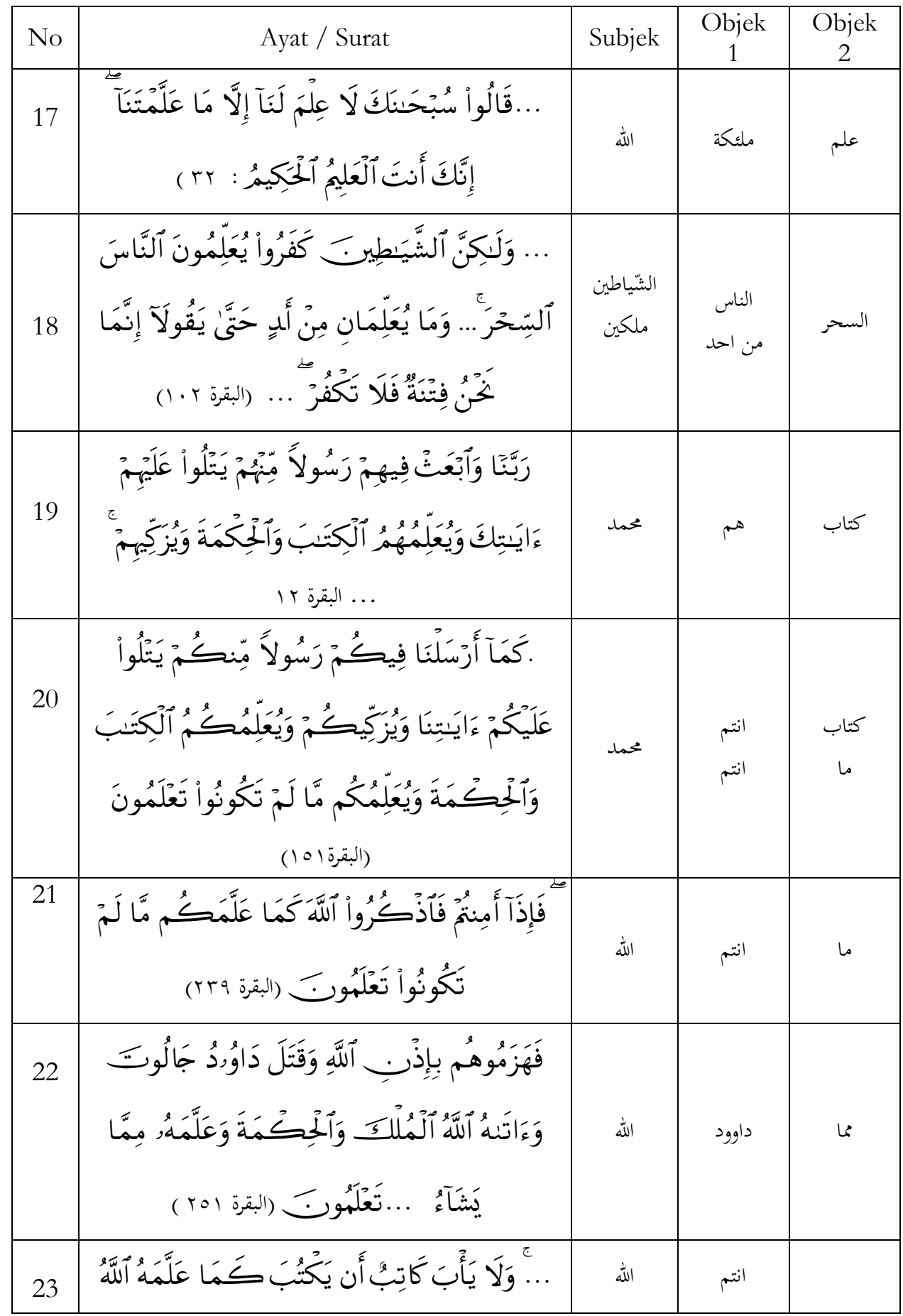


Wawan Setiawan

\begin{tabular}{|c|c|c|c|c|}
\hline No & Ayat / Surat & Subjek & $\begin{array}{c}\text { Objek } \\
1\end{array}$ & $\begin{array}{c}\text { Objek } \\
2\end{array}$ \\
\hline & 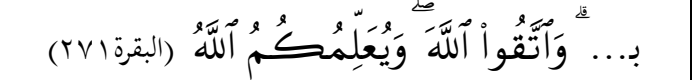 & & & \\
\hline 24 & 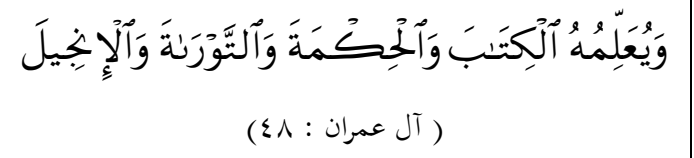 & اللة & عيسى & كتاب \\
\hline 25 & 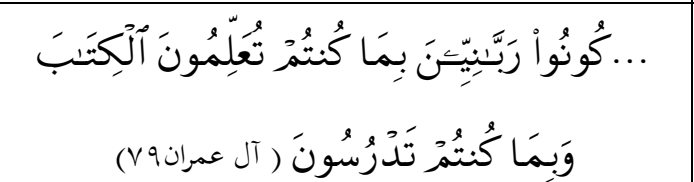 & انتم & & كتاب \\
\hline 26 & 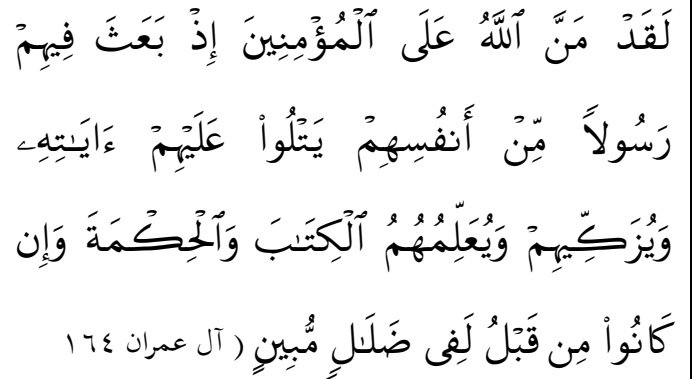 & محمد & هم & كتاب \\
\hline 27 & 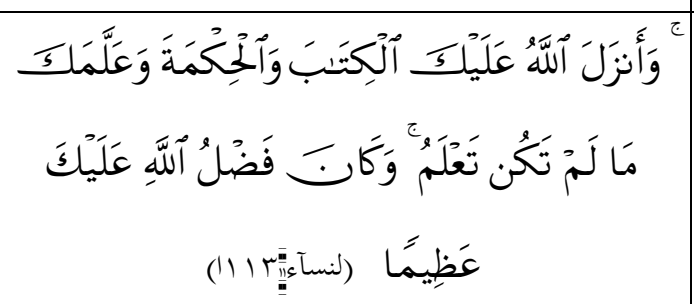 & الله & حمّمد & L \\
\hline 28 & 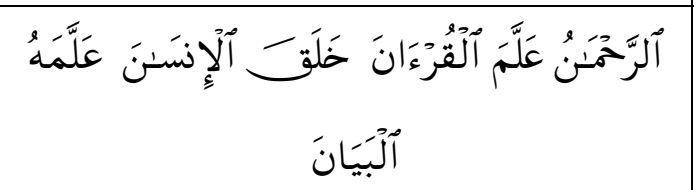 & نلله & 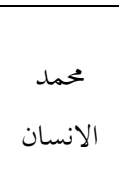 & 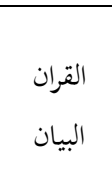 \\
\hline 29 & 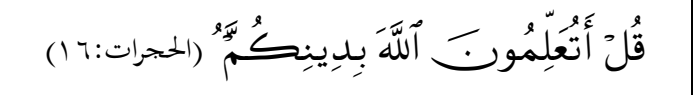 & انتم & الله & دين \\
\hline 30 & 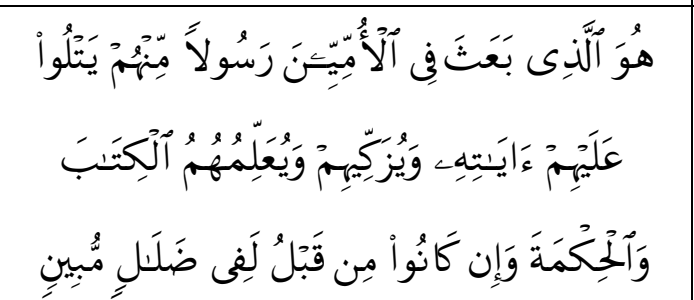 & محمد & هم & كتاب \\
\hline
\end{tabular}




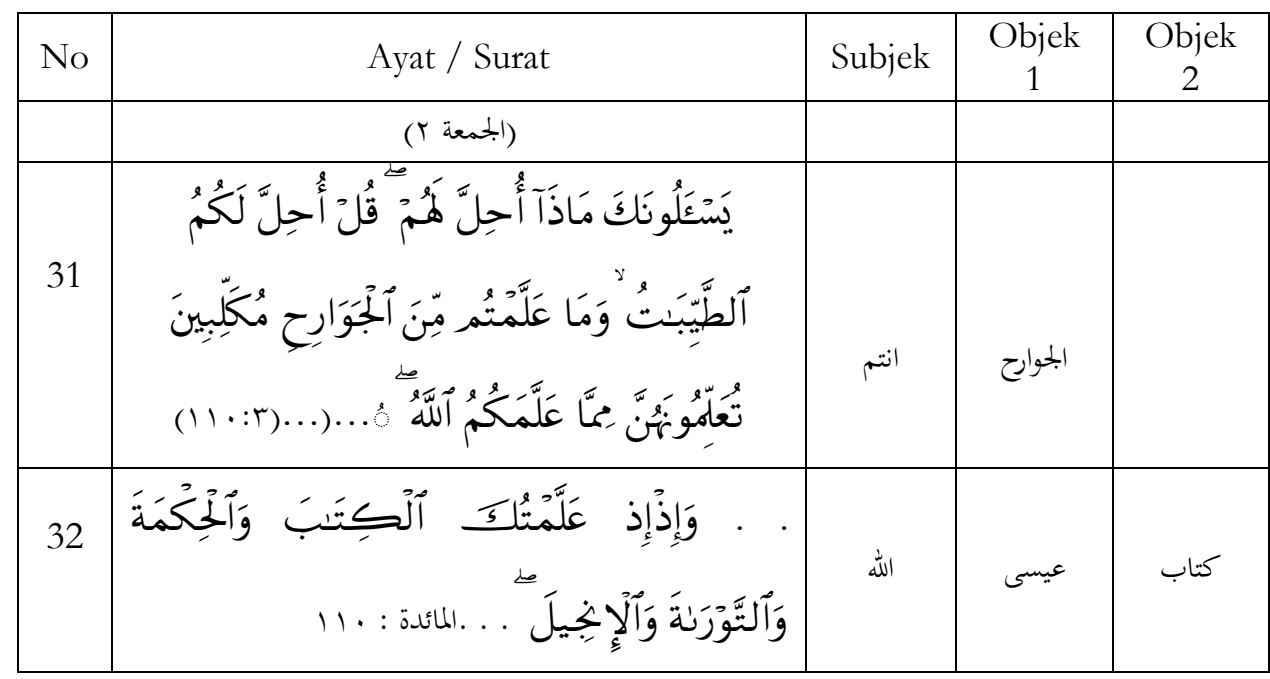

Dilihat dari jabatan kata dalam kalimat, ayat-ayat di atas menunjukkan pelaku ( fầil), sasaran ( mafûl 1) dan materi yang disajikan (mafûl 2 ). Dari 38 kata 'allama - yu'allimu terdapat 24 ayat yang menunjukkan bahwa Allah merupakan pelaku, dua ayat untuk malaikat, enam ayat bagi rasul dan lima di antaranya tertuju pada Rasul Muhammad (No: 20, 21, 21, 26, 30) serta manusia pada umumnya. Penanda yang menjadi sasaran ta'lim Allah kepada para rasul ada 18 ayat, empat di antaranya diperuntukan bagi Rasul Muhammad. Hanya satu penanda untuk malaikat dan dua bagi binatang berburu (No: 31), selebihnya untuk manusia biasa. Demikian pula dalam ayat yang menunjukkan Rasul Muhammad sebagai pelaku ta'lîm, sasarannya banyak ditujukan kepada manusia. Hal ini terlihat dalam pencantuman dlâmîr 'bum' (No. 20, 26, 30), dan 'kum' (N0. 21). Atas dasar itu dapat diketahui bahwa secara umum sasaran ta'lim adalah manusia.

Mengenai mafûl 2 (materi), ta'lîm tidak selalu menunjukkan materi yang diajarkan secara jelas. Artinya kadang-kadang saja kata tersebut menyebutkan materi tertentu, seperti pada ayat (N0.10, 15, 21, 22, 23, 28, 31) dan kadangkadang tidak disebutkan secara jelas. Materi ta'lîm yang tidak disebut secara jelas menunjukkan bahwa Allah mengajarkan sesuatu di luar jangkauan manusia. Rasyid Ridha, (tth: 402) menafsirkan ayat N0. 21 'kamâ 'allamakum mâ lam takênû ta'lamûna' dengan "Allah mengajar engkau Muhammad hal yang gaib secara mutlak".

Ayat-ayat yang tidak menunjukkan objek sama sekali adalah N0. 2, 16, 24, dan surat Al-'Alaq: 4 (N0. 1). Dalam ayat itu, kata benda yang disebutkan hanya kata 'qalam' yang merupakan alat tulis, meskipun yang dimaksud adalah "tulisan" (Zamakhsyari, tth: 270). Pengertian itu dikemukakan pula oleh Quraish Shihab (1997: 100) dengan argumen "i ibtibâk" yang berarti dua susunan kalimat yang bergandengan tetapi masing-masing tidak menyebutkan keterangan yang 
semestinya, karena pada salah satu susunan kalimat telah dijelaskan. Menurutnya, ayat ke empat dan kelima surat al-'alaq menjelaskan ada dua cara yang ditempuh Allah dalm mengajar manusia; Pertama, Dia (Allah swt) mengajarkan kepada manusia dengan pena (tulisan) yang harus dibaca oleh manusia; Kedua, melalui pengajaran secara langsung tanpa alat tentang hal yang tidak diketahui oleh manusia. Di antara materi ta'lim (Objek 2) yang disebutkan secara jelas adalah 'ilmu (N0. 9, 11), sibr (N0. 4, 5, 18), sy'ir (N0. 3), AlQuran/Kitab (N0. 21, 25, 26, 27, 31), kepandaian membuat baju besi (N0. 12), kepandaian memahami suara burung (N0.14); demikian pula ayat-ayat yang menunjukkan misi profetis Muhammad seperti terlihat dari empat ayat yaitu N0. 20, 21, 26, dan 30. Pada keempat ayat itu diketahui bahwa salah satu misi beliau adalah ta'lîm (mengajarkan) al- kitâb wa al-bikmata", dan 'wa yu'allimukum mâ lam takêû̀ ta'lamûn" yang ditafsirkan Al-Baghawi, (tth: 73) dengan "Allah mengajarkan ilmu gaib".

Meski pada ayat ( N0. 31) "wa mâ 'allamtum min al-jawârihi tu'allimûnabunna ..." tidak jelas apa materi yang diajarkan, namun ada dugaan bahwa yang dimaksud adalah 'keterampilan atau cara berburu bagi binatang pemburu', karena ayat itu berbicara tentang kehalalan makanan yang dinyatakannya, yaitu "Katakanlah dihalalkan bagi mereka yang baik-baik dan (buruan yang ditangkap) oleh binatang buas yang telah kamu ajari dengan melatihnya untuk berburu, maka makanlah apa yang ditangkapnya untukmu". Kehalalan makanan hasil buruan itu disertai syarat bahwa "binatang pemburunya sudah terlatih sehingga hasil buruannya bisa dinisbatkan kepada manusia yang menyuruhnya (Al-Maragi, tth: 57). Demikian pula N0. 12, “wa 'allamnâbu shan'ata labûsin” (Allah mengajarkan kepada Dawud kepandaian membuat baju besi) Dari dua ayat itu diperoleh pemahaman bahwa melatih keterampilan juga termasuk sasaran ta'lim.

Keterampilan, banyak macamnya, mulai dari keterampilan untuk mencari nafkah sampai keterampilan untuk mempertahankan diri. Dalam sebuah hadis dinyatakan "'allimû abnấâkum al-sibâhata wa al-rimâyata". Perintah mengajarkan berenang dan memanah mengisyaratkan betapa pentingnya anakanak memiliki kemampuan pertahanan diri untuk menghadapi kerasnya kehidupan. Atas dasar uraian tersebut dapat dinyatakan bahwa ta'lim adalah bentuk verb-noun artinya bisa berfungsi sebagai kata kerja dan kata benda. Sebagai kata kerja, dapat diartikan mengajar. Di sini terkandung proses belajar mengajar yang intinya interaksi antara guru (subjek) dan murid (objek 1). Sebagai kata benda, ta'lim berarti pengajaran yang mengandung muatan pesan, informasi, pengetahuan, serta keterampilan. Dengan demikian ta'lim berarti menyampaikan informasi, pengetahuan, serta melatihkan keterampilan.

Pernyataan di atas mengesankan bahwa mengajar menempatkan murid berada pada posisi yang pasif sedangkan guru aktif mentransfer pengetahuan. Berarti murid hanya mendengar atau mencatat saja. Di sisi lain dari sejumlah ayat yang mengandung lafad 'allama - yu'allimu secara umum sasarannya (objek 1) adalah manusia yang merupakan keturunan Adam. Adam sebagai simbol 
manusia disebut-sebut sebagai mahluk yang memiliki akal. Sebagai pemilik akal, manusia memungkinkan untuk memperoleh pengetahuan yang diperlukan dalam rangka melaksanakan misi kekhalifahannya, sebagaimana diisyaratkan dalam ayat N0. 17 "wa 'allama Âdama al-asmâ'a kullahâ..."

Dari surat 16: 78 berikut ada petunjuk bahwa manusia memiliki tiga alat untuk memperoleh pengetahuan.

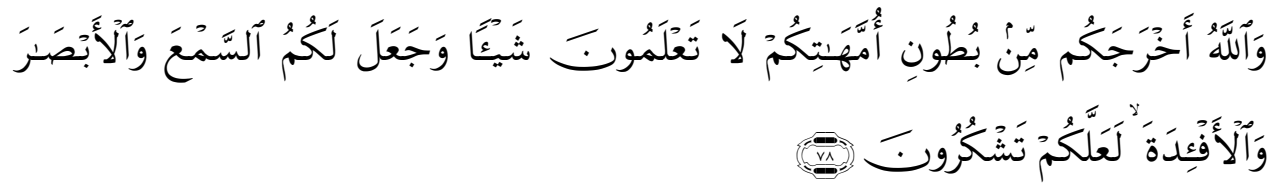

Dan Allah mengeluarkan kamu dari perut ibumu dalam keadaan tidak mengetahui sesuatupun, dan Dia memberi kamu pendengaran, penglibatan dan hati agar kamu bersyukur.

Informasi yang masuk ke dalam otak diperoleh melalui indera penglihatan dan pendengaran (sam'u dan abshâr). Pendengaran adalah alat pertama untuk menyerap sejumlah informasi. Penglihatan adalah alat indera untuk mengobservasi hal-hal yang empirik, sedang af 'idat yang bentuk mufrad-nya fu' $\hat{a} d$ adalah alat batiniah yang digunakan untuk mengolah dan mengembangkan informasi yang didapat dari kedua indera tadi. Aspek akal sebagai potensi merupakan ciri khas manusia sehingga layak memegang fungsi kekhalifahan. Melalui aspek akal inilah muncul kreativitas setelah melalui proses sam'u dan abshar. Dengan demikian sasaran ta'lim (mengajar) adalah akal yang berarti pula bahwa ta'lîm tidak seperti pendapat banyak orang yaitu "naqlu al - ma'lûmât min almu'allim ilâ al-muta'allim" (tranformasi pengetahuan) yang membuat peserta didik (subjek belajar) menjadi pasif (objek). Pengajaran seperti itu mengakibatkan para peserta didik menjadi tidak memiliki keberanian untuk mengemukakan pendapat, tidak menjadikan peserta didik kreatif dan mandiri apalagi untuk memecahkan masalah dalam hidupnya. Suasana interaksi seperti itu kurang mengembangkan fungsi otak. Ta'limm tidak memosisikan akal manusia sebagai gudang penyimpan pengetahuan tetapi merupakan suatu upaya untuk memungsikan akal atau daya pikir dan memosisikannya sebagai 'alat produksi dalam pabrik'.

Dari beberapa ayat lain diperoleh bukti bahwa Al-Quran banyak mengajak manusia untuk melakukan olah pikir. Cara itu sangat tepat bagi ajaran yang berlaku sepanjang zaman sehingga memungkinkan peserta didik mengembangkan pemahamannya dalam upaya mencari alternatif baru seiring dengan perkembangan zaman. Penekanan ta'lim dengan semata-mata pengalihan pengetahuan, pada satu sisi memang bermanfaat, namun di sisi lain harus disadari bahwa perubahan situasi dan kondisi akan selalu terjadi sehingga manusia dituntut untuk senantiasa belajar menyesuaikan diri dengan tuntutan dan perkembangan zaman yang terjadi. Menurut Dodi Tisnamikaya dalam 
Conny R Semiawan (ed), (1991: 46), "Suatu peoses pendidikan yang benar-benar inovatif harus mempersiapkan peserta didik untuk menghadapi perubahan dan menjawab tantangan lingkungan secara efektif dan efisien.

Memungsikan akal tidak hanya akan memperoleh pengetahuan belaka atau melahirkan teori keilmuan dalam berbagai aspeknya tetapi juga dapat mengantarkan manusia ke arah kesadaran akan kebesaran, kekuasaan, dan keesaan Allah swt. Dengan demikian akan ditemukan kebenaran pernyataan AlQuran surat Fushshilat 53 bahwa "Kami akan memperlihatkan kepada mereka tanda-tanda (kekuasaan). Kami di segala penjuru dan pada diri mereka sendiri, sehingga jelaslah bagi mereka bahwa Al-Quran itu adalah benar". Kesadaran ini amat penting dalam upaya menumbuhkan ketaqwaan. Memungsikan akal akan membuat manusia berpikir meneliti alam sekitarnya seperti diperintahkan oleh Al-Quran. Sehubungan dengan itu tugas guru sebagai mu'allim adalah membimbing bagaimana supaya potensi akal/daya pikir peserta didik sebagai subjek belajar bisa berfungsi secara aktif, mengingat pikiran yang aktif dapat melahirkan gagasan yang diwujudkan dalam bentuk kreativitas yang menjadi pendorong kemajuan peradaban. Menurut HAR Tilaar (1999: 72), pendidikan bukan terjadi dalam keadaan pasif tetapi melalui proses interaktif. Proses tersebut dapat mendorong berkembangnya budaya karena melalui kemampuan kreatif peserta didik dapat melakukan inovasi.

Upaya memungsikan akal/daya pikir merupakan tugas guru dalam menyiapkan manusia yang mampu menghadapi kehidupan yang terus berkembang. Manusia terdidik harus mampu menyesuaikan diri serta mampu memecahkan persoalan yang dihadapi terutama kehidupan di masa depan yang ditandai dengan serba kompetisi, transparansi, efisiensi, kualitas tinggi, dan profesionalisasi " (Indra Djati Sidi, 2001: 38). Jika mengingat pada prinsip belajar 'min al-mahdi ilâ al-lahdí (belajar seumur hidup) maka optimalisasi seluruh potensi serta kreativitas manusia yang dilakukan sepanjang hayat akan mengurangi dampak kejam perubahan yakni menyebabkan pengetahuan orang cepat usang. Indra Djati Sidi, (2001: 25) kemudian menegaskan kepada guru untuk secepatnya mengubah paradigma teaching (mengajar) menjadi learning (belajar). Dengan perubahan ini, pendidikan pun dipandang sebagai 'proses pembelajaran bersama antara guru dan peserta didik'. Guru dalam konteks ini, termasuk dalam proses belajar sama-sama mengandaikan bahwa lingkungan sekolah merupakan learning society (masyarakat pembelajar). Implikasi dari learning society itu mengakibatkan proses belajar-mengajar akan lebih bersifat problem solving oriented daripada material oriented. Dalam kondisi itu proses belajar-mengajar tidak hanya berorientasi kepada hasil dalam bentuk menumpuknya pengetahuan, melainkan lebih kepada bagaimana belajar dari lingkungannya, bagaimana memecahkan masalah yang dihadapinya, sehingga kreativitas siswa bisa berkembang. Orientasi seperti ini diprediksi bisa menghindari pendidikan "gaya bank" seperti yang dikritik Paulo Freire. Tentu saja guru perlu mencari metode yang bisa lebih mengutamakan aktivitas serta kreativitas murid, metode yang 
memberi kesempatan kepada para siswa seluas mungkin untuk menghayati sendiri peristiwa yang dipelajarinya. Dalam proses interaksi belajar-mengajar, guru harus mampu merangsang siswa sebagai subjek belajar untuk menggunakan akalnya secara bebas dan bertanggung jawab, serta memandang mereka sebagai manusia yang mempunyai peluang untuk mengembangkan seluruh potensi yang dimilikinya. Bagaimanapun juga karakteristik pendidikan Islam menurut Azyumardi Azra,(1999: 10) adalah "pengakuan akan potensi dan kemampuan seseorang untuk berkembang dalam suatu kepribadian. Setiap pencari ilmu dipandang sebagai makhluk Tuhan yang perlu dihormati dan disantuni agar potensi-potensi yang dimilikinya dapat teraktualisasi dengan sebaik-baiknya". Metode yang dimaksud adalah metode yang memberi kesempatan kepada para siswa seluas mungkin untuk; a) menyerap informasi masuk ke dalam struktur kognisinya, sehingga tercapai kebermaknaan yang optimal; dan b) menghayati sendiri peristiwa yang dipelajarinya agar terjadi proses afektif dan internalisasi nilai (Nung Muhajjir, 1996: 108).

Perubahan paradigma pengajaran di atas mestinya berdampak pada pergeseran peran guru di kelas. Dalam paradigma baru, guru bukan lagi satusatunya sumber belajar, karena orang bisa belajar dari berbagai sumber. Guru tidak lagi berperan sebagai pengajar/penyampai informasi, melainkan akan lebih banyak berperan sebagai mitra, motivator, fasilitator dan konselor yang mengajak dan merangsang pengembangan potensi para peserta didik. Perubahan peranan ini tidak berarti tugas guru menjadi ringan sebab menurut T. Raka Joni (1991: 113), guru tetap menjadi tokoh kunci bahkan kini dengan dua misi penyampaian pesan sekaligus yaitu: (a) membentuk pengetahuan, keterampilan dan sikap nilai yang berasal dari bidang bahan ajaran yang dibinanya dan; dan (b) memberikan partisipasi nyata di dalam upaya pencapaian tujuan utuh pendidikan yang telah ditetapkan. Pesan (b) ini dapat diberikan mulai dari kesadaran diri sebagai mahluk Tuhan, kecintaan kepada tanah air dan bangsa serta kemampuan dan kemauan untuk belajar sepanjang hayat.

\section{Tarbiyyah}

Lafad tarbiyyah tidak dijumpai dalam Al-Quran, yang ada hanyalah lafadlafad yang mengandung unsur rab yang berjumlah 980 dalam 15 lafad; enam

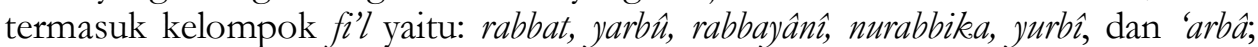
sembilan termasuk kelompok ism yaitu rabb, arbâb, ribbiyyûn, rabbâni, rabâỉb, râbiyan, râbiya, ribâ, dan rabwat. Umar Yusuf Hamzah, (1997: 6) mengutip pandangan Imam Baidawi mengatakan bahwa kata yang mengandung unsur rab itu dapat dikembalikan kepada tiga asal yakni "rabâ - yarb $\hat{u}$ ' yang berarti "namâyanmû" (berkembang), "rabiya-yarbâ" yang berarti "nasya'a" (tumbuh), "rabba yurabbi" yang berarti "ashlabahû, tawallâ amrahû wa qâma 'alaybi wa ra'âhu" (memperbaiki, mengurus, menuntun, dan menjaga). Dalam penggunaannya kata tersebut mempunyai banyak arti yaitu; 1) pendidikan, bantuan, dan peningkatan.

2) menghimpun, memobilisasi dan mempersiapkan; 3) perbaikan dan 
pengasuhan; 4) keagungan dan kepemimpinan; serta 5) pemilik dan juragan (AlMaududi, 1981: 26).

Nampak bahwa kata tarbiyyah merupakan bentuk mashdar dari salah satu tiga asal di atas yaitu rabba-yurabbi. Kata itu sering diartikan sebagai pendidikan yang khusus bagi manusia. Umar Yusuf Hamzah, (1997: 9) menyatakan bahwa

kegiatan tarbiyyah meliputi unsur; 1) memelihara fitrah anak dan memantapkannya dengan penuh perhatian; 2) menumbuhkan bakat - bakat; 3) mengarahkannya menuju kesempurnaan; dan 4) dilakukan secara bertahap. Penggunaan tarbiyyat yang hanya untuk manusia bukanlah tanpa kritik karena sebetulnya sasarannya bersifat umum yaitu menumbuhkan sesuatu setahap demi setahap sehingga menuju kesempurnaan (Asfahani, tth: 189).

Syed Naquib Alatas (1992: 66) menyatakan bahwa tarbiyyah itu berarti mengasuh, menanggung, memberi makan, mengembangkan, memelihara, membuat, menjadikan bertambah dalam pertumbuhan. Oleh karena itu penerapan dalam bahasa Arab-nya tidak bisa dibatasi pada manusia semata. Bahkan medan semantiknya dapat diperluas kepada spesies lain. Dengan demikian sasaran tarbiyyah tidak hanya manusia tetapi juga tumbuhan dan hewan. Mengingat sasaran tarbiyyah sangat luas, maka penggunaan tarbiyyat untuk pendidikan saja kurang tepat, karena istilah pendidikan hanya dilakukan khusus untuk manusia. Istilah tarbiyyat bukan istilah yang paling tepat, benar dan identik dengan pendidikan meskipun salah satu sasaran tarbiyyah adalah manusia.

Pendidikan untuk manusia dalam pengertian luas merupakan pengembangan pribadi dalam semua aspeknya dengan penjelasan bahwa yang dimaksud 'pengembangan pribadi' ialah yang mencakup pendidikan oleh diri sendiri, pendidikan oleh lingkungan, dan pendidikan oleh orang lain"(Tafsir, 1997: 26). Menurut Mochtar Buchori (1994: 81) saat ini kata mendidik dan pendidikan lebih sering digunakan sebagai sebutan bagi semua upaya untuk mengembangkan tiga hal, yakni pandangan hidup, sikap hidup dan keterampilan hidup pada diri seseorang atau sekelompok orang. Dari pernyataan itu diketahui bahwa pendidikan dipandang sebagai kegiatan dalam arti sempit dari seseorang kepada orang lain, tidak mencakup pendidikan diri sendiri dan pengaruh lingkungan alam sekitar.

Berikut ini adalah sebagian lafaz yang mengandung unsur tarbiyyah bagi manusia;

1. Surat Al-Isra: 24;

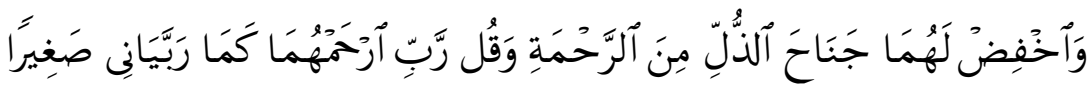

Dan rendabkanlah dirimu terhadap mereka dengan penub kesayangan dan ucapkan 'wahai Tuhanku kasibilah mereka keduanya sebagaimana mereka berdua telah mendidik aku waktu kecil'.

2. Surat al-Syu'ara: 18 ; 


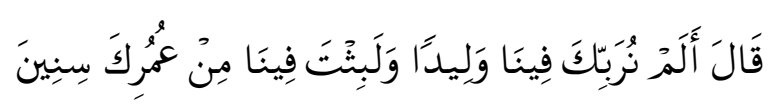

Fir'aun menjawab 'bukankah kami telah mengasubmu di antara (ke-luarga) kami wak.tu kamu masib kanak-kanak dan kamu tinggal bersama kami beberapa tahun dari umurmu'.

3. Surat Al-Fatihah: 2-3;

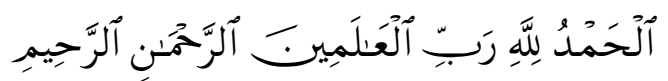

Segala puji bagi Allah Tuhan semesta Alam. Maha Pemurah lagi Maha Penyayang.

4. Surat Al-Syu'ara: 77-80;

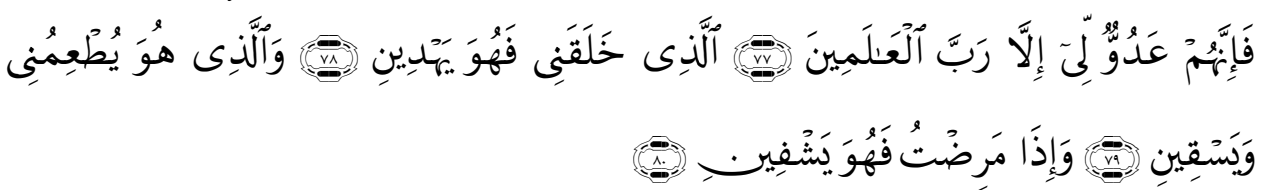

Karena sesunggubnya apa yang kamu sembah itu adalah musubku, kecuali tuhan semesta Alam. (yaitu Tuhan) yang telah menciptakan aku. Maka Dialah yang menunjuk aku. Dan Tubanku (adalab) Yang Dia memberi makan dan minum, kepadaku, dan apabila aku sakit Dialah yang menyembubkanku.

5. Surat Ali Imran : 146

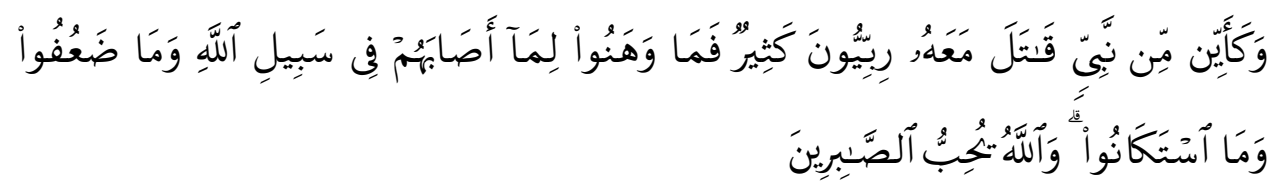

Dan berapa banyaknya nabi yang berperang bersama-sama mereka sejumlah besar dari pengikut (nya) yang bertaqwa. Mereka tidak menjadi lemah karena bencana yang menimpa mereka di jalan Allah dan tidak lesu dan tidak (pila) menyerah (kepada musub). Allab menyukai orang-orang yang sabar.

Dari ayat-ayat di atas diperoleh gambaran bahwa yang menjadi pelaku proses adalah Allah (N0. 3 dan 4), manusia yaitu kedua orang tua (N0. 1), dan Firaun (N0. 2). Mereka disebut murabbi. Adapun yang menjadi sasaran proses, secara umum adalah manusia.

Ayat N0: 1 memuat perintah Allah kepada manusia untuk berperilaku hormat kepada kedua orang tuanya didorong rasa kasih sayang serta takut untuk melakukan hal yang tidak sesuai dengan kedudukan mereka seperti yang bisa dilihat dari wa ikhfidl labumâ janâha al-dzulli mi al-rabmati. Ayat itu juga menyuruh manusia untuk memohon kepada Allah yang maha pendidik supaya mereka mendapat limpahan kasih sayang-Nya, atas jasanya memelihara mereka sejak kecil seperti dalam ungkapan "... kamâ rabbayânî shagîrâ". 
Jika pendidikan diartikan suatu upaya mewujudkan manusia sempurna yang bercirikan fisik sehat dan kuat, akalnya cerdas dan pandai, hatinya penuh iman, maka dalam kata "rabbayânî shaghîrâ" terkandung makna bahwa tarbiyyat orang tua terhadap anaknya adalah penumbuhkembangan fisik berupa perawatan atau pemeliharaan sejak ia kecil (bahkan sejak dalam kandungan) yang meliputi pemberian makan pakaian tempat tinggal serta kebutuhan lainnya.

Salah satu bentuk penumbuhkembangan fisik anak-anak yang merupakan tanggung jawab orang tua bisa dilihat dari pemberian peluang yang cukup untuk menyusukan ASI seperti dinyatakan surat Al-Baqarah: 233, "wa al-wâlidâtu yurdli'na awlâdahunna bawlayni kâmilayni liman arâda an yutimma al-radlâ'atà'. Dalam hadis riwayat Bukhari dari Aisyah dinyatakan; Ketika Hindun binti Uthbah lapor kepada Rasul tentang nafkah dari suaminya yang tidak mencukupinya, beliau berkata; "Ambillah secukupnya buat kamu dan anak-anakmu".

Penumbuhkembangan fisik juga diisyaratkan oleh ayat N0: 2; "alam Nurabbika finâ walìdan wa labitsta finâ min 'umrika sinîna" yang merupakan ungkapan Firaun kepada Musa. Menurut Al-Maraghi (tth: 52), Firaun menghitung jasanya yang telah diberikan kepada Musa dalam mengurus dan mengantarkannya ke masa dewasa serta memberikan fasilitas yang dibutuhkan seperti makanan pakaian dan tempat tinggal. Dalam tafsir Al-Jalâlayn disebutkan telah memelihara Musa tinggal di istananya sejak ia bayi sampai ia berusia 30 tahun (Jalaluddin as-Sayuthi dan Jalaluddin al-Mahalli, tth: 303).

Karena dalam kata rabb terkandung makna "kepemilikan" maka orang tua yang melakukan tarbiyyah hendaknya mengingat bahwa pemilik mereka sebenarnya adalah Allah Yang Maha Pencipta dan Pemelihara. Kepemilikan yang sebenarnya itu dinyatakan dalam puluhan ayat yang salah satunya ayat N0. 3 yaitu "Al-bamdu Li Allâbi rabbi al-'álamîn".

Realisasi tarbiyyat Allah terhadap manusia, bisa dirinci yaitu; Pertama, pemeliharaan existensi dalam arti menumbuhkan sejak kecil hingga dewasa dan meningkatkan kekuatan jiwa serta akalnya; Kedua, memelihara agama dan ahlaknya melalui wahyu yang diturunkan kepada salah seorang rasul untuk menyempurnakan akal dan jiwa mereka (Al-Maragi, th: 81).

Substansi pemeliharaan Tuhan dalam penumbuhkembangan potensi fisik, secara eksplisit dinyatakan dalam lanjutan ayat N0. 4 ".....illâ Rabba al-âlamîn,

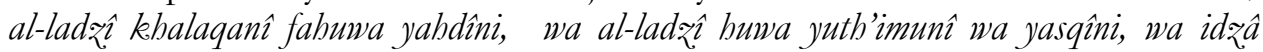
maridltu fabuwa yasyfini...." (yaitu Tuhan) yang menciptakan aku. Dialah yang menunjuki aku, yang memberi makan dan minum kepadaku, dan apabila aku sakit, Dialah yang menyembuhkan aku.

Kalau konsep tarbiyyah pada ayat-ayat di atas mengandung pesan penumbuhkembangan fisik, pada ayat N0. 5 kata itu mengandung pesan pembinaan afeksi. Hal itu bisa dilihat dari kata ribbiyyûna yang diikuti kata famâa wahanû limâ ashâbabum fî sabîli Allâhi, wa mâ dla'ufû, wa mâ istakânû wa Allâbu yubibbu al-shâbirin (Dan berapa banyak nabi yang berperang bersama mereka 
sejumlah besar dari pengikut (nya) yang bertaqwa (ribiyyûn). Mereka tidak menjadi lemah karena bencana yang menimpa mereka di jalan Allah, tidak lesu, dan tidak (pula) menyerah (kepada musuh). Allah menyukai orang-orang yang sabar. Pada ayat 144 dan 145 disebut-sebut pula kata syukur, yang merupakan sikap batin penuh rasa terima kasih atas segala nikmat yang dianugerahkan Allah.

Ayat itu terkait dengan peristiwa kekalahan kaum muslimin dalam perang Uhud yang banyak menelan korban kaum muslimin. Quraish Shihab,(2001: 219) menyatakan, "ketika itu muncul isu bahwa Nabi Muhammad telah gugur. Mendengar isu tersebut pasukan kaum muslimin yang memang telah kacau, bertambah kacau dan sebagian besar mereka meninggalkan medan tempur. Sebagian yang lemah imannya mengusulkan agar meminta perlindungan kepada tokoh musyrik ketika itu, yakni Abu Sufyan". Di sisi lain ayat itu mengecam sikap mereka dengan membandingkannya kepada ribiyyûn (pengikut nabi) yang terluka, bahkan terbunuh. Para pengikut nabi itu sedikitpun tidak merasa lemah dan patah semangat tatkala sebagian mereka terluka atau gugur, meski yang gugur itu nabi mereka, karena mereka berperang bukan karena nabi, tetapi semata - mata karena Allah (Al-Maraghi, tth: 92).

Lemah dan lesu biasanya terkait dengan jasmani yang bisa jadi akibat hilangnya semangat, karena ada rasa takut atau sisi psikologis lain, dan ini mengantarkan kepada sikap menyerah. Secara tidak langsung melalui ayat itu Allah menganjurkan kaum muslimin meniru ribbiyyûn untuk tidak merasa lemah lesu serta tidak menyerah sekaligus mengajak untuk bersabar sebagai suatu sikap kemampuhan mengendalikan diri, serta tekad yang kuat, tabah dalam melaksanakan kewajiban termasuk dalam perang menghadapi musuh.

Pembinaan afeksi, terlihat pula pada ayat N0.1 meski samar-samar. Sikap perbuatan ihsan berupa kemauan berdoa, rasa hormat anak terhadap orang tua sebagai bentuk balas budi adalah satu segi dari tarbiyyahorang tua yang ditanamkan kepada anak-anaknya. Hal ini sulit diterima akal karena mereka tidak pernah menerima perbuatan yang sama dari orang tua mereka. Dari pernyataan itu ada kesan bahwa jiwa ribbiyyah adalah kepemilikan sisi afeksi semacam kemampuan mengendalikan emosi, sabar, berani, optimis dan syukur. Singkatnya tarbiyyat mengandung pula pesan pengembangan afeksi terdidik.

Jika ditelusuri lebih lanjut, ada hal menonjol yang harus menyatu dengan seorang murabbi. Pada ayat N0: 1, kata rabbayânî didahului dua kata rabmat. Rahmat yang pertama menunjukkan bahwa menghormati orang tua harus timbul dari rasa kasih sayang, sedang rahmat yang kedua (dalam bentuk f'il amr) merupakan permohonan sang anak kepada Tuhan Yang Maha Pendidik untuk melimpahkan kasih sayang atas jasa mereka karena mereka telah melimpahkan kasih sayang yang salah satunya adalah jerih payahnya dalam menumbuhkembangkan fisik anak-anaknya sejak kecil.

Dalam sebuah hadis riwayat Bukhari dari Abu Hurairah diketahui bahwa Rasulallah Saw. mencium Hasan bin Ali, sedang Al-Aqra bin Habis al-Tamimi duduk di sampingnya. Al-Aqra berkata; "Aku mempunyai sepuluh orang anak, 
belum pernah aku mencium seorang pun di antara mereka. Rasulallah memandang padanya, lalu berkata "man lâ yarham lâ yurham" (barangsiapa tidak mengasihani, dia tidak akan dikasihani).

Keharusan seorang murabbi memiliki kasih sayang dinyatakan pula dalam surat Al-Fatihah "Al-bamdu li Allâhi Rabbi al-'alamîn”. Kata rabbi al'âlamîn diartikan Rasyid Ridha, (tth:3) dengan "yang mendidik, mengatur mengurus, dan menata alam semesta sejak pertama hingga akhir". Ayat itu diikuti oleh ayat yang memuat kata al-rahmân dan al-rahîm yang sering diartikan dengan Maha Pengasih dan Maha Penyayang. Ini menunjukkan bahwa tarbiyyah Allah (pengurusan dan pemeliharaan) terhadap alam termasuk manusia, sama sekali bukan atas dasar suatu pamrih melainkan atas limpahan kasih sayang-Nya terhadap seluruh mahluk. Di sisi lain, ketika menyebut kata Rab, maka dalam kandungan makna kata ini terhimpun semua sifat Allah yang dapat menyentuh mahluk. Pengertian rubûbiyyah (kependidikan/pemeliharaan) mencakup pemberian rizki, pengampunan, dan kasih sayang (Shihab,2001: 30). Pada ayat N0. 2 tidak dijumpai lafaz rahmat sebelum atau sesudah "alam nurabbika". Musa tidak mendapat kasih saaing Firaun, bahkan Firaun menampakkan sikap ketidaksenangannya, namun Musa mendapat kasih sayang permaisurinya seperti pernyataan surat Thaha: 39; "...wa alqaytu alayka mababbatan minnî wa litushna'a 'alâ 'aynî' (dan aku telah melimpahkan kepadanya kasih sayang yang datang dari padaku, dan supaya kamu diasuh di bawah pengawasanku ). Bahkan selanjutnya ia berada di bawah asuhan ibunya sendiri seperti dinyatakan pada ayat selanjutnya “....Faraja'nâkea ilâ ûmmika kay taqarra 'aynuhâ wa lâ tahzana..." (... maka Kami mengembalikanmu kepada ibumu agar senang hatinya dan tidak berduka cita...). Ibunya diangkat Firaun khusus sebagai perempuan susuan, perawat, pengasuh, dan pelayan segala kebutuhan Musa, dan Firaun memberikan upah untuk itu (Saleh Al-Khalid, 1999: 85.) Berarti sasaran tarbiyyah adalah pembinaan aspek fisik, aspek afeksi yang terkait dengan suasana hati, dan prosesnya dilakukan melalui pendekatan kasih sayang.

Di sekolah, guru bisa memerankan tugas seorang murabbi, karena itu tugas pendidikan yang secara operasional diserahkan kepada manusia yang menyandang jabatan murabbi, sangat wajar mengemban jiwa rubûbiyyah yang substansinya menggambarkan jiwa ketuhanan yang tak pilih kasih dan tak pandang sayang. Jiwa ribbiyyah (ribiyyûn) semacam sikap sabar, tak putus asa yang melambangkan kekokohan dan keyakinan pun merupakan gambaran sebagai sikap keagamaan yang kuat. Sebagai seorang murabbi, guru dapat disebut berhasil bila para peserta didiknya tidak hanya memperoleh indek prestasi akademik yang tinggi, karena hal itu hanyalah salah satu aspek ukuran kesuksesan, tetapi juga sisi afeksi semacam citra diri, motivasi, aspirasi, dinamis, optimis, kemampuan mengendalikan emosi, mawas diri, jujur, baik sangka, berani karena benar, penuh harga diri dan kemauan kuat yang tak bisa dirinci setidaknya sama penting dengan prestasi akademik. Semua itu dikelompokan kepada sisi afeksi manusia yang menyangkut suasana hati. Menurut Nung Muhajjir (1994: 55), afeksi 
merupakan fungsi psikologis yang berhubungan dengan interaksi di antara orang-orang dan melibatkan suasana hati, perasaan, tujuan, citra diri, aspirasi dan motivasi.

Seorang guru dalam arti murabbi, mempunyai tugas mengembangkan kemampuan pribadi peserta didik. Artinya peran guru tidak dibatasi pada peran pengajaran. Mochtar Bukhari, (1994: 85) menyatakan bahwa tugas guru tidak hanya mengajar tetapi juga mendidik. Jika guru hanya terpaku kepada mengajar, maka hasil yang diperoleh ialah siswa-siswa yang cukup luas pengetahuannya tetapi tidak cukup mantap kepribadiannya. Dalam konteks Indonesia, pangkal krisis multi dimensi ini adalah kebobrokan ahlak yang ujungnya bermuara kepada simpulan kegagalan pendidikan. Boleh jadi, akar masalahnya ada pada ketidakberesan dalam praktik pendidikan, misalnya pengajaran yang seharusnya merupakan berwujud pendidikan, dipersempit menjadi pemberian informasi semata sehingga sekolah kurang menunaikan fungsinya sebagai tempat pendidikan.

Menurut pengamatan Made Pidarta, (1997: 23), praktik pendidikan di Indonesia belum benar-benar mengacu kepada pencapaian tujuan. Praktik pendidikan ini sebagian besar hanya mengembangkan kognisi peserta didik ditambah sejumlah psikomotor. Menurut T Raka Joni (1991: 120) pembentukan pribadi dapat dicapai bila pengembangan afeksi dilakukan secara optimal, upaya pencapaian pun dilakukan secara integratif. Setiap episode belajar mengajar harus sekaligus merupakan perwujudan pendidikan oleh karena itu pekerjaan mengajar guru lebih dari sekedar meneruskan informasi dan melatihkan keterampilan.

Dalam upaya mendidik, guru tidak hanya harus menguasai bahan ajar, namun juga harus memahami nilai-nilai yang dapat ditransfer melalui bahan ajar yang disajikan. Setiap mata pelajaran di balik materi yang dapat disajikan, secara jelas memiliki nilai dan karakteristik tertentu yang mendasari materi itu sendiri. Tugas guru adalah mengembangkan potensi siswa semaksimal mungkin lewat penyajian mata pelajaran (Zamroni, 2000: 75).

Pendidikan berupaya membantu agar proses perkembangan subjek didik selaras dengan nilai-nilai yang baik sehingga setiap menyampaikan pengetahuan atau melatihkan keterampilan apapun harus dilandasi nila-nilai yang bisa diterima. Pengajaran tentang salat misalnya harus sekaligus mengimplisitkan nilai yang terkandung di dalamnya semacam ketaatan, kedisiplinan, kedamaian dengan sesama. Memberikan pengetahuan teknologi haruslah sekaligus mengimplisitkan nilai-nilai kemanusiaan. Menumbuhkan kreativitas hendaknya sekaligus diberi pembekalan bagaimana mengantisipasi efek dan dampak terhadap nilai kemanusiaan (Nung Muhajjir, 1994: 73). Dengan demikian seorang guru harus mampu mengimplisitkan nilai yang terkandung di balik setiap penyajian bahan ajar, atau pengajaran hendaknya merupakan perwujudan tujuan pendidikan. 
Pembinaan afeksi juga sangat penting untuk melindungi peserta didik dari dampak negatif kemajuan zaman. Perkembangan teknologi informasi saat ini yang sangat cepat bukan sekedar bermanfaaat untuk kehidupan mansia tetapi juga bisa berdampak negatif pada penyusutan nilai-nilai luhur. Dalam kondisi seperti ini guru sebagai murabbi bukan hanya harus mempunyai wawasan pengetahuan, tetapi juga dituntut untuk memerankan fungsi konservasi dalam arti melindungi nilai-nilai luhur dari kepunahan semacam keimanan, keihlasan, tolong-menolong, tenggang rasa, optimis, kejujuran dan keadilan. Bila nilai-nilai seperti itu terkikis, tata kehidupan akan goyah, bahkan runtuh sekaligus. Guru juga harus mampu berperan sebagai filter dalam arti mampu menyaring nilainilai negatif semacam, egois, individualis, hedonis dan kebebasan tanpa batas. Guru bahkan harus menjadi teladan dalam berperilaku. Guru masa depan itu laksana seorang resi/begawan. Ia menguasai sains dan teknologi. Ia membawa peserta didik ke dalam pengenalan sains dan teknologi serta menjadi personifikasi moral dan keyakinan agama atas anak didiknya (Tilaar, 1999: 177).

\section{Tazkiyyah}

Kata tazkiyyat merupakan bentuk mashdar dari "zakkêa - yuzakkề" yang termasuk bentuk tsulatsi mazîd dengan menambahkan satu huruf kepada kata "zakâ-yazk $\hat{u}$ " yang berarti berkembang dan barakah (Ibnu Mandzur, th: 36). Kata itu cenderung menunjuk kepada kesucian diri yang merupakan ungkapan pengembangan keutamaan serta kesempurnaan jiwa dengan cara menghindari perbuatan dosa. Kata tazkiyyah tidak dijumpai dalam Al-Quran, yang ada hanyalah bentuk mâdhî dan mudhâri' nya dan terulang puluhan kali, 10 diantaranya yaitu Surat Al-Syams: 9, An-Najm: 32, Nur: 21, Al-Baqarah: 174, Ali Imran: 77, An-Nisa: 49, Al-Baqarah: 151, Ali imran: 164, dan Al-Jumat: 2.

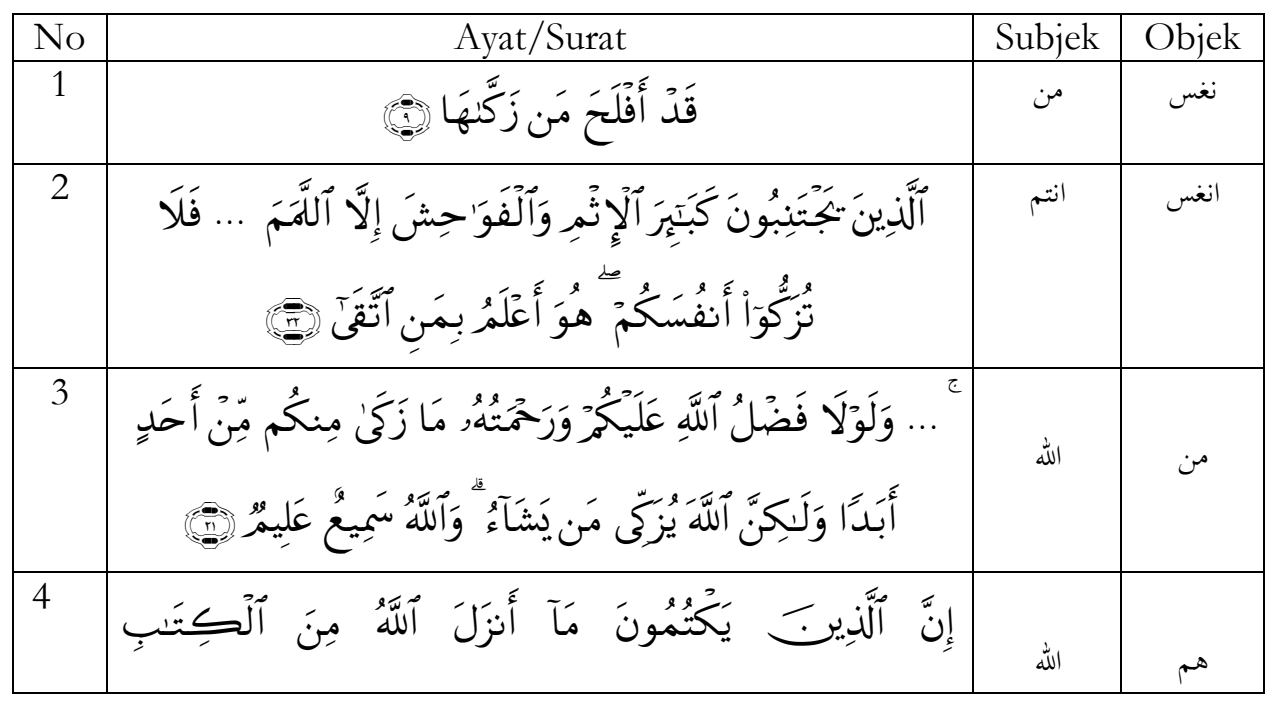




\begin{tabular}{|c|c|c|c|}
\hline & 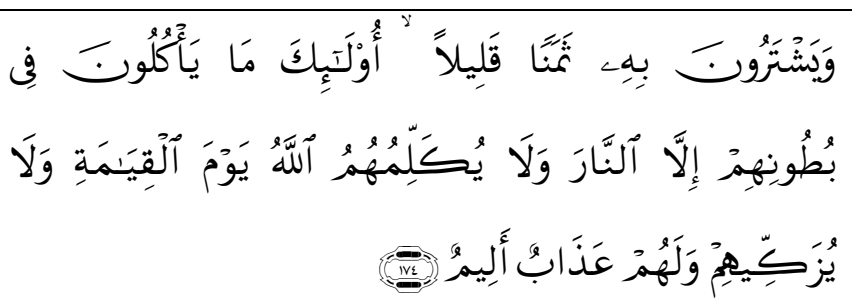 & & \\
\hline 5 & 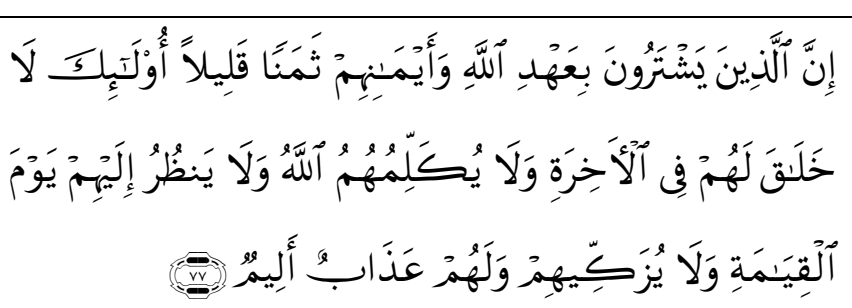 & الله & هم \\
\hline 6 & 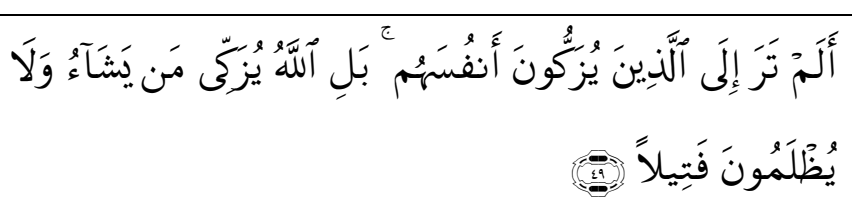 & ه & من \\
\hline 7 & 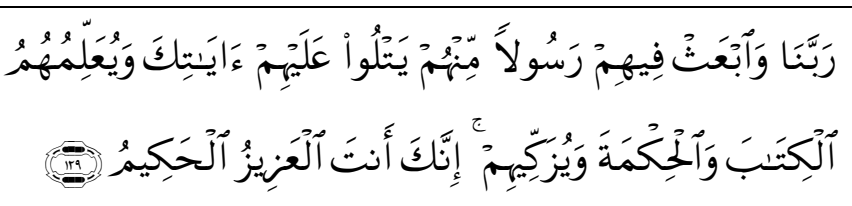 & رسول & هم \\
\hline 8 & 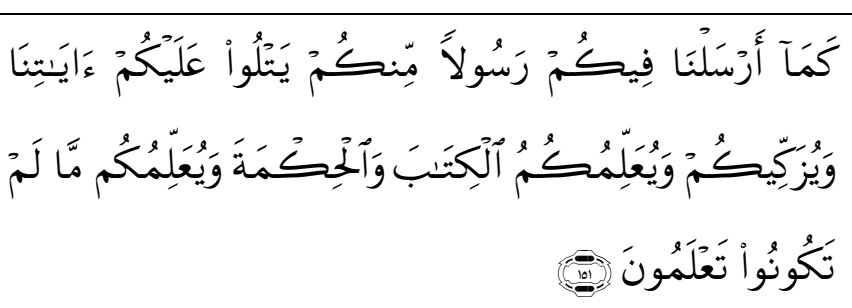 & م رسول & انتم \\
\hline 9 & 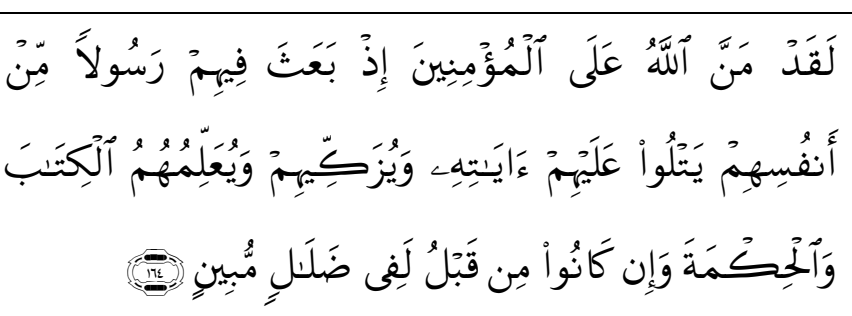 & رسول & هم \\
\hline 10 & 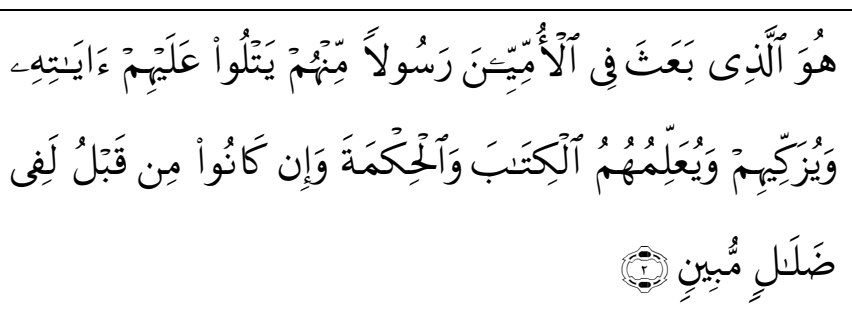 & رسول & هم \\
\hline
\end{tabular}


Pada surat Al-Syams ayat 8, fa al-hamahâ fujûrahâ wa taqwhâ (maka Allah mengilhamkan kepada jiwa itu [jalan] kefasikan dan ketakwaannya) dinyatakan bahwa jiwa manusia memiliki dua kecenderungan untuk berbuat baik atau buruk karena manusia memiliki kalbu dan hawa nafsu. Manusia memiliki peluang sama untuk berbuat itu. Allah memberi kebebasan bagi mereka untuk menentukan pilihannya. Perilaku manusia adalah hasil tarik-menarik antara kalbu dan hawa nafsu. Jika kalbu mendominasi hawa nafsu, maka tindakan atau sikap manusia akan cenderung positif, dan ia dipandang tengah melakukan tazkiyyah. Jika hawa nafsu menguasainya, maka manusia akan cenderung berbuat jahat, dan ia dipandang sedang melakukan tadsiyyah. Surat As-Syams: 9-10 menegaskan, Qad aflaha man zakkâhâ wa qad khâba man dassâhâ, (keberuntungan bagi orang yang melakukan tarkiyyat dan kerugian bagi orang yang melakukan tadsiyyah). Keberuntungan dan kerugian diungkapkan dengan qad dan fi'l mâdhî yang menunjukkan kepastian. Dalam surat Al-m'uminûn: 1-6 disebutkan bahwa orang yang mendapat keuntungan antara lain mereka yang khusyu dalam salat, menunaikan zakat, memelihara kemaluannya dan memelihara amanah. Perbuatan tersebut dinilai sebagai bentuk tazkiyyah. Perbuatan yang tidak menguntungkan disebutkan dalam 11 ayat antara lain terdapat dalam kata, kâfir (Al-Qashash: 82), zhâlim (Al-Qashash: 37), sibr (Thaha: 69), berbuat bohong (Yunus: 17), khamr, maysir, anshâb, ąlâm (Al-Maidah: 9). Gabungan 'qad dan ' $k$ hâba' terdapat pula dalam dua ayat surat Thâhâ: 61 dan 111 yang menyatakan kerugianlah bagi orang yang mengada-adakan kedustaan dan melakukan kezhaliman.

Ayat N0: 2 pada surat An-Najm: 32 menyatakan bahwa ciri orang yang berbuat baik adalah yang menjauhi dosa-besar seperti syirik, membunuh tanpa hak tetapi segera bertaubat. Di sini tersirat bahwa ada kelemahan pada manusia

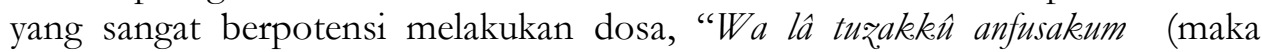
apabila kamu telah tahu hal itu, janganlah punya anggapan kamu akan terhindar dari perbuatan dosa) (Quraish Shihab, 2001: 60). Manusia dilarang untuk menganggap dirinya suci karena Allah melihat dan mengetahui perbuatan serta ucapan manusia.

Pada ayat N0. 3 surat an-Nur: 21 dicantumkan ayat yang membicarakan perbuatan zina dan musyrik. Dalam ayat 21 itu kaum muslimin diperintahkan untuk tidak mengikuti langkah syetan karena syetan selalu menyuruh berbuat keji dan munkar. Kemudian disebutkan, kalaulah bukan karunia Allah dan rahmatNya niscaya tak seorang pun bisa terhindar dari perbuatan keji dan munkar. Allahlah yang menyucikan orang-orang yang bertaubat dengan menerima taubat mereka (Quraish Shihab, 2001: 137). Ayat-ayat tersebut menyatakan bahwa, tidak melakukan dosa besar, tidak merasa suci diri, tidak terlibat dengan perbuatan seperti zina dan musyrik serta tidak mengikuti langkah syetan, menghindari sikap merasa suci, sikap pemaaf dan berlapang dada, dinilai sebagai bentuk "tarkiyyah. Pernyataan, "sekiranya bukan karunia Allah" mengandung makna bahwa tarkiyyah harus diupayakan. 
Ayat N0. 4, 5, dan 6, adalah tiga ayat yang memuat tarkiyyah dalam konteks orang kafir. Ayat N0. 4 Surat Al-Baqarah: 174 membicarakan kelakuan ahli kitab. Ayat itu erat kaitannya dengan ayat sebelumnya yaitu celaan atas sifat orang kafir yang selalu mengikuti tradisi nenek moyang mereka yang tidak sesuai dengan aturan Ilahi (ayat 170), suruhan kepada orang beriman untuk memakan makanan yang thayyib dan bersyukur (ayat 172), dan rincian makanan yang diharamkan (ayat 173). Penjelasan tentang makanan-makanan yang diharamkan, dikemukakan dalam konteks mencela masyarakat jahiliyyah, baik di Mekah maupun di Medinah, karena mereka membolehkan memakan binatang yang mati tanpa disembelih (Shihab, 2001: 360)

Di antara kelakuan Ahli Kitab yang diceriterakan dalam ayat 174, adalah "suka menyembunyikan kebenaran, tidak menyampaikannya dan mengubah kebenaran yang ditukar dengan sedikit harta (Al-Maragi, tth: 51). Perilaku mereka itu pada hakikatnya sama saja dengan memakan harta yang haram yang dilambangkan dengan api neraka, karena ia mendapat murka Allah. Adapun maksud dari wa lâ yuzak.kîhim, yaitu, Allah tidak mensucikan mereka dalam arti tidak membersihkan dosa mereka dengan jalan mengampuninya, (maka ketika) mereka mati (dan) tetap dalam kekufuran (Rasyid Ridha, tth: 104).

Ayat N0. 5 Surat Ali 'Imrân: 77, masih berbicara tentang orang Yahudi yang suka berlaku curang dalam muamalah dan erat kaitannya dengan ayat 75 yang menyebutkan sosok manusia yang mampu menunaikan amanah dan sosok penghianat yang tak mampuh menunaikannya sekecil apapun. Perilaku khianat mengundang lahirnya pengingkaran janji dan kebohongan, bahkan kebohongan tidak jarang dikukuhkan dengan sumpah. Oleh karena itu ayat ini berbicara tentang orang-orang yang berkhianat dan berbohong menggunakan sumpah untuk meraih keuntungan material di dunia. Ayat ini turun sehubungan dengan Huy bin Akhtab dan Kaab bin Asyraf serta Yahudi lain yang menyembunyikan apa-apa yang terdapat dalam Taurat. Mereka menggantinya, mengubah dan bersumpah bahwa itu datang dari Allah (Ridha, tth: 342). Orang yang inkar janji, disebut sebagai orang yang menukarkan janjinya dengan harta yang sedikit karena sangat biasa orang berbohong demi materi. Allah tidak akan menyucikan mereka, yakni tidak akan memaafkan dosa-dosa yang telah mengotori jiwa-jiwa mereka (Shihab, 2001: 306).

Ayat N0. 6 Surat An-Nisâ: 49 merupakan salah satu rangkaian ayat yang membicarakan sifat buruk orang Yahudi misalnya mereka lebih memilih jalan sesat daripada petunjuk (ayat 44), yang suka mengubah (menambah dan mengurangi) firman Allah (ayat 46). Pada ayat 47, mereka diajak untuk beriman kepada Al-Quran. Pada ayat 48 dinyatakan bahwa Allah tidak akan mengampuni dosa syirik. Ayat ini mengandung tuduhan kepada kaum Yahudi sebagai pelaku syirk dan mengandung seruan untuk bertauhid secara murni meski di sini tidak disebut adanya perkataan atau tindakan mereka yang dianggap syirik (Sayyid Quthb, 1978: 678). 
Ayat 49 menyatakan perbuatan jelek Yahudi yang menganggap dirinya suci (bersih diri). Ayat itu memperingatkan kaum muslimin agar tidak berbuat hal serupa, karena manusia tidak berhak menganggap dirinya suci, saleh, tidak berbuat dosa, dan merasa dekat dengan Allah. Allahlah yang menyucikan jiwa manusia karena yang lebih tahu hati serta amalan mereka (Bal Allâhu Yuzak.kî).

Ayat-ayat di atas menyatakan bahwa tazkiyyah dikaitkan dengan upaya menghindari perbuatan tercela seperti perbuatan syirk memakan harta haram, khianat, serta sikap kesombongan dengan mengaku bersih diri dari perbuatan dosa. Ayat N0. 7, 8, 9, dan 10, adalah empat ayat yang menunjukkan salah satu tugas Rasul Muhammad yaitu tarkiyyat.

Ayat No 7 Surat Al-Baqarah: 129 merupakan sebagian dari doa Nabi Ibrahim yang menginginkan diutusnya seorang rasul untuk orang beriman dari kalangan mereka sendiri, yang misinya membacakan ayat-ayat Allah, mengajar kitab dan hikmah serta tazkiyyah. Ayat N0 8 Surat Al-Baqarah: 151 merupakan bukti keterkabulan doa itu.

Pada ayat N0. 9 Surat Ali Imran: 164 dinyatakan bahwa kedatangan Rasul merupakan suatu anugerah Allah bagi orang mukmin, karena merekalah yang mampu meraih manfaat atas kehadirannya. Ayat N0 10 Surat Al-Jumat: 2 merupakan penegasan Allah atas keterkabulan doa Nabi Ibrahim. Dalam ayat itu kata taqkiyyah dikaitkan dengan ummy dan dlalâl. Al-Quran menamakan masyarakat Arab sebagai ummiyyin. Kata "ummy" terambil dari kata umm yang arti harfiyahnya "ibu" dalam arti bahwa seorang ummiy adalah yang keadaannya sama dengan keadaan pada saat dilahirkan oleh ibunya dalam hal kemampuan membaca dan menulis (Quraish Shihab, 1997: 71). Menurut Fakhruddin ar-Razi, (tth: 3) ummy itu dinisbatkan kepada masyarakat Arab yang tidak mempunyai kitab, tidak bisa membaca dan menulis. Menurut Toshihiko Izutsu, (1997: 82) umiyyin adalah "orang Arab penyembah berhala". Menurut Ragib Asfahani, (tth: 299), ummy itu "al-ghaflatu wa al-jahâlatu." Agaknya beliau mengaitkannya dengan Jahiliyyah.

Meski jahiliyyah berarti dalam keadaan kebodohan, namun yang dimaksud Al-Quran bukanlah bodoh dalam arti tidak memiliki pengetahuan atau kecerdasan berpikir, tetapi mereka buta terhadap agama yang benar, meninggalkan doktrin monotheisme, tidak peduli dengan aturan-aturan serta hukum yang diturunkan Allah. Simpulan itu didasarkan atas penelitian terhadap surat 3: 154, 5: 50, 33: 33, dan 48: 26 (Qawaid, 1989: 4).

Sayyid Quthb (1978: 508-510) merinci perilaku jahiliyyah antara lain: 1) perlakuan terhadap wanita seperti pembunuhan anak wanita dengan alasan takut memberi nafkah, merasa aib karena cacat, atau aib karena memiliki anak wanita; 2) praktik perkawinan/hubungan biologis yang merendahkan derajat wanita seperti nikah istibdâi yakni seorang suami menyuruh istrinya untuk dicampuri orang lain untuk mendapat keturunan darinya, nikah musyârakab; 3) parktik kemusyrikan berupa penyembahan berhala; dan 4) penyakit ahlak/sosial seperti minum khamr dan judi. 
Dari empat ayat di atas dua di antaranya menyatakan, Wa in kânû min qablu lafî dlalâlin mubîn, yang berarti, "sebelum kedatangan nabi, mereka berada dalam kesesatan keyakinan, pemahaman kehidupan, tujuan, tradisi dan perilaku, aturan perundang - undangan, kemasyarakatan serta ahlak" (Sayyid Quthb,1978: 511). Kata "dlalâl" (sesat) dalam beberapa ayat Al-Quran dihubungkan derngan kerusakan aqidah misalnya; "Sesungguhnya orang-orang kafir sesudah beriman, kemudian bertambah kekafirannya, sekali-kali tidak akan diterima tobatnya; dan mereka itulah orang-orang yang sesat" (Ali Imran: 90). Wahai orang-orang yang beriman, tetaplah beriman kepada Allah dan Rasul-Nya dan kepada kitab yang Allah turunkan kepada Rasul-Nya, serta kitab yang Allah turunkan sebelumnya. Barang siapa yang kafir kepada Allah, malaikat-malaikat-Nya, kitab-kitab-Nya, rasul-rasul-Nya dan hari kemudian, maka sesungguhnya orang itu telah sesat sejauh-jauhnya (Al-Nisa: 136). Sehubungan dengan itu maka fungsi tarkiyyah Rasul adalah menyucikan jiwa mereka dari ahlak tercela, bentuk kemusyrikan, kekufuran dan perilaku kotor Jahiliyyah (Zamakhsyari, tth: 102). Sayyid Quthb (1978: 507) menyatakan tazkiyyah itu membersihkan dari noda lahir dan batin, seperti perbuatan syirk, khurafat, mitos-mitos, simbol tradisi yang merendahkan derajat kemanusiaan, dan noda-noda jahiliyyah yang mengotori perasaan, tata nilai dan pikiran mereka. Oleh karena itu kedatangan Rasul adalah suatu karunia besar yang membimbing mereka dari jalan sesat ke jalan terang.

Pengutusan Rasul terkait dengan upaya perbaikan kondisi masyarakat yang berada dalam kerusakan aqidah berupa parktik-praktik kemusyrikan, serta kerusakan sistem hidup bermasyarakat. semua itu erat hubungannya dengan sistem nilai. Tugas Rasul bukan hanya sekedar ta'lim atau mengajarkan materi ilmu, melainkan juga tazkiyyah yang lebih bermuatan menanamkan nilai, yang mengarahkan seluruh aktivitas manusia kepada tauhid sebagai lawan kemusyrikan.

Islam datang pada saat manusia jauh dari tauhid maka pengutusan Rasul adalah upaya untuk menegakkan ajaran tauhid yang telah dikotori oleh kemusyrikan yang melanda masyarakat waktu itu. Tauhid merupakan ajaran dasar dan terpenting dalam Islam, yang berintikan keimanan kepada Tuhan. Menurut Ahmad Tafsir, (1996: 4) inti agama itu adalah iman. Iman itu dalam hati bukan di kepala, maka iman tidak dapat diajarkan. Meskipun demikian, Nabi mengajarkan bahwa keberimanan itu perlu ditanamkan. Hal itu harus dimulai dengan penanaman kebiasaan pengamalan kewajiban atas agama berupa ibadat disertai penghayatannya sejauh mungkin sehingga manusia sadar akan kemahlukannya dan keagungan Tuhannya.

Harun Nasution, (1986: 40) menyatakan bahwa ibadat berimplikasi memberikan latihan rohani yang diperlukan manusia. Semua ibadat dalam Islam bertujuan membuat roh senantiasa tidak lupa pada Tuhan bahkan senantiasa dekat kepadaNya. Keadaan senantiasa dekat kepada Tuhan dapat mempertajam rasa kesucian seseorang. Rasa kesucian yang kuat akan menjadi rem bagi hawa 
nafsu untuk melanggar nilai moral, peraturan dan hukum. Oleh karena itu di samping sebagai latihan spritual, ibadat juga merupakan latihan moral.

Sejarah mencatat langkah konkret pertama yang rasul lakukan setelah hijrah adalah membangun mesjid sebagai sarana ibadat. Para sahabat sebagai murid beliau tidak hanya menerima informasi ilmu, melainkan juga nilai. Inilah yang membangkitkan kesadaran mereka akan kepentingan kesucian jiwa sebagai modal utama dalam menciptakan ketenangan hidup. Di bawah bimbingan beliau mereka melakukan penyucian jiwa sehingga menjadi daya kontrol dalam hidup keseharian. Menurut M. Quraish Shihab (1992: 172), Rasulallah saw. yang dalam hal ini bertindak sebagai penerima Al-Quran, bertugas untuk menyampaikan petunjuk-petunjuk tersebut, menyucikan "taqkiyyab" dan mengajarkan "ta'lim". Menyucikan dapat diidentikkan dengan "mendidik", sedangkan perbuatan mendidik senantiasa terkait dengan nilai - nilai.

Bagi ummat Islam, nilai itu adalah tauhid (Keesaan Tuhan). Nilai itulah yang mengarahkan seluruh aktivitas manusia dan kepadanya bermuara seluruh gerak langkah dan detak jantung. Keesaan berisi satu inti di pusatnya dan sejumlah orbit unicentris di sekelilingnya. Pada orbit-orbit itulah prinsip keesaan mengejawantahkan diri dalam tingkat yang berbeda (Shihab,1992: 249). Konsep Keesaan Tuhan (tauhid) adalah masalah keimanan sedang keimanan terdapat dalam kalbu yang tak bisa diajarkan melainkan harus ditanamkan melalui pembiasaan.

Mengacu kepada tugas Rasul di atas ada suatu petunjuk bahwa tugas guru tidak terbatas hanya sekedar pembentukan tata fikir (ta'Iim), tetapi juga tąkiyyat. Sebagai muzakki guru mengemban tugas untuk mengembangkan potensi tauhid (fitrah) yang dibawa sejak lahir, serta memeliharanya jangan sampai dihinggapi kemusyrikan. Semua anak dilahirkan atas dasar fitrah, maka kedua orang tuanyalah (pengaruh lingkungan) menjadikannya menganut agama Yahudi, Nasrani, atau Majusi (HR Bukhari Muslim, Ahmad dari Abu Hurairah). Caranya antara lain melalui pembiasaan pengamalan ibadah dalam hidup keseharian. Perwujudan nilai-nilai melalui pembiasaan akan melahirkan sosok manusia yang kalbunya penuh iman yang berdampak terhadap hidup keseharian.

Kebiasaan akan lahir manakala dilakukan secara berulang. Di sekolah, pembiasaan bisa pula dilakukan guru misalnya melakukan kegiatan ibadat ritual semacam salat wajib secara berjamaah, penyembelihan hewan qurban, berdoa atau membaca beberapa ayat Al-Quran sebelum dan sesudah belajar, mengucapkan salam bila bertemu, sebelum masuk dan meninggalkan ruangan, juga menciptakan suasana religius. Sekolah dituntut untuk menyediakan fasilitas yang bisa mendukung kegiatan tersebut.

\section{SIMPULAN}

Dari 38 kali penyebutan 'allama-yu'allimu, secara umum sasarannya manusia yang mempunyai akal. Orientasi ta'lîm bukan sekedar penyampaian pengetahuan dan keterampilan, namun menekankan pemberdayaan akal (tata 
pikir). Penekanan ta'lim kepada upaya pemberdayaan akal sangat penting dalam upaya menyiapkan manusia untuk menghadapi kehidupan yang terus berkembang di mana manusia harus mampu menyesuaikan diri serta mampu memecahkan persoalan yang dihadapi. Memberdayakan akal akan memungkinkan siswa mengembangkan pemahamannya dalam upaya mencari alternatif baru seiring perkembangan yang terjadi. Memberdayakan akal dapat melahirkan kreativitas yang memungkinkan terjadinya inovasi. Memberdayakan akal bukan hanya upaya memperoleh banyak pengetahuan, tetapi dapat mengantar manusia ke arah kesadaran akan Kemahabesaran Allah. Kesadaran ini amat penting untuk menumbuhkan rasa ketaqwaan. Orientasi tarbiyyah bersifat umum baik menyangkut pengembangan potensi fisik, maupun psikis, namun dalam hal pengembangan psikis lebih diarahkan kepada afeksi seperti menyangkut suasana hati, perasaan, citra diri, motivasi, ketahanan mental sebagai ciri ribbiyyunn. Di sisi lain tarbiyyah dilakukan dengan pendekatan kasih sayang sebagai cermin sifat rububiyyah Allah. Tazkiyyah terkait dengan kalbu, merupakan tempat keimanan. Sasaran tarkiyyah terfokus kepada kegiatan pemeliharaan/pengembangan nilai-nilai (potensi keimanan), serta menghindari kemusyrikan. Kegiatan itu dilakukan dengan cara penanaman kebiasaan mengamalkan kewajiban agama berupa amalan ibadat disertai penghayatan akan Kemahabesaran Allah.

\section{DAFTAR PUSTAKA}

Al-Asfahani, Raghib, t.th. Mu'jam mufradât alfẫh Al-Qurân, Beirut: Dar Al-Fikr. al-Maraghi, Musthafa, 1974. Tafsîr al-Marâghî, Beirut: Darul Fikr.

An-Naquib Alatas, Muhammad, Syed 1994. Konsep Pendidikan Dalam Islam, Bandung: Mizan.

Ar-Razi, Fakhruddin, 1985. Al- Tafsìr al-Kabîr wa Mafattĥh al-Ghayb, Beirut: Darul Fikr.

Azra, Azyumardi, 1997. Pendidikan Islam Tradisi dan Modernisasi menuju Milenium Baru, Jakarta: Wacana Ilmu.

Bukhori, Mochtar, 1994. Spektrum Problematika Pendidikan di Indonesia, Jogja: Tiara Wacana.

Hamzah, Yusuf, Umar, 1994. Ma'alim al-tarbiyyati fí Al-Qur'an wa Al-Sunnat, Amman; Darul Usamah.

Izutsu, Toshihiko, 1997. God And Man In The Qoran, terjemah Agus Fahri Husen dkk, Jogja: Tiara Wacana.

Muhadjir, Noeng, 1993. Ilmu Pendidikan dan Perubahan Sosial Suatu Teori Pendidikan, Jogjakarta: Rake Sarasin, Edisi. 4.

Nasution, Harun, 1996. Islam Rasional Gagasan dan Pemikiran, Bandung: Mizan. Pidarta, Made, 1997. Landasan Kependidikan, Jakarta: Rineka Cipta.

Quraish Syihab, M. 2000. Tafsir Al Mishbah, Pesan, Kesan, dan Keserasian Al-Qur'an, Jakarta: Lentera Hati. 
Quthb, Sayyid, 1978. Fi z̧hilâli Al-Qur'ân, Beirut: Darusysyuruq Rasyid Ridha, Muhammad tth. Tafsîr al-Manâr, Beirut: Darul Makrifah.

Semiawan, Conny R. (ed), 1991. Mencari Strategi Pengenbangan Pendidikan Nasional Menjelang Abad XXI, Jakarta: Grasindo Utama.

Sidi, Djati, Indra 2001. Menuju Masyarakat Belajar Menggagas Paradigma Baru Pendidikan, Jakarta: Logos Wacana Ilmu.

Tafsir, Ahmad, 1994. Ilmu Pendidikan dalam Perspektif Islam, Bandung: Rosda Karya.

Zamakhsyari, t.th. Tafsîr al - Kasysyâf, Beirut: Darul Fikr,.

Zamroni, 2000. Paradigma Pendidikan Masa Depan, Jogjakarta: Biograf Publishing House. 